\title{
The Effect of Tocotrienol-Rich Fraction on Oxidative Liver Damage Induced by Fenitrothion
}

(Kesan Fraksi Kaya Tokotrienol ke atas Kerosakan Oksidatif Hepar Diaruh Fenitrotion)

\author{
PUTRI AYU JAYUSMAN, Siti BALKIS BUdIN*, IZATUs SHIMA TAIB \& AHMAD ROHI GHAZALI
}

\begin{abstract}
Exposure to organophosphate pesticide including fenitrothion (FNT) has led to many adverse effects on human health. However, a potent antioxidant like palm oil tocotrienol-rich fraction (TRF) can reduce oxidative damage in various pathological conditions, could also reduce the adverse effects by FNT. The aim of this study was to evaluate the effect of TRF on oxidative liver damage in FNT induce hepatotoxicity in experimental rats. A total of 40 male Sprague-Dawley rats were randomly divided into four groups of 10, namely control, TRF, FNT and TRF+FNT group. TRF (200 mg/kg body weight) and FNT $(20 \mathrm{~m} / \mathrm{kg}$ body weight) were administered through oral gavage for 28 days. Corn oil which served as vehicle was given orally to the control group. At the end of the study period, liver and blood was taken for oxidative damage and biochemical evaluation and histological observation. TRF supplementation prevents oxidative liver damage by reducing the hepatic malondialdehyde (MDA) and protein carbonyl (PCO) level significantly. Besides, TRF also restored the endogenous antioxidants particularly reduced glutathione (GSH), glutathione peroxidase (GPX) and ferric reducing/antioxidant power (FRAP). TRF also prevent liver damage by reducing the liver enzymes, alanine aminotransferase (ALT) and aspartate aminotransferase (AST). The attenuation of liver damage by TRF was also showed histologically. In conclusion, TRF supplementation showed a potential in preventing oxidative liver damage in FNTtreated rats by reducing the oxidative damage and improving the antioxidant status.
\end{abstract}

Keywords: Antioxidant; oxidative stress; palm oil; vitamin E

ABSTRAK

Pendedahan kepada organofosfat termasuk fenitrotion (FNT) telah menyebabkan kesan sampingan pada kesihatan manusia. Walau bagaimanapun, antioksidan yang poten seperti fraksi kaya tokotrienol minyak sawit (TRF) berupaya untuk mengurangkan kerosakan oksidatif yang mungkin juga berupaya untuk mengurangkan kesan kerosakan FNT. Kajian ini dilakukan untuk menilai kesan TRF ke atas hepatotoksiti tikus aruhan FNT. Sebanyak 40 ekor tikus jantan Sprague-dawley dibahagikan secara rawak kepada empat kumpulan, sepuluh ekor setiap satu iaitu kumpulan kawalan, $T R F, F N T$ dan TRF +FNT. TRF $(200 \mathrm{mg} / \mathrm{kg} \mathrm{bb})$ dan FNT $(20 \mathrm{mg} / \mathrm{kg} \mathrm{bb})$ diberikan secara oral paksa selama 28 hari. Minyak jagung yang merupakan pengangkut telah diberikan secara oral kepada kumpulan kawalan. Pada akhir kajian, hepar dan darah diambil untuk menilai kerosakan oksidatif dan status biokimia serta pemerhatian histologi. Suplementasi TRF melindungi hepar daripada mengalami kerosakan oksidatif dengan menurunkan aras malondialdehid (MDA) dan protein karbonil (PCO) hepar secara signifikan. Tambahan pula, TRF juga mengembalikan aras antioksidan endogenus terutamanya glutation terturun (GSH), glutation peroksidase (GPX) dan pengurangan ferik /kuasa antioksida (FRAP). TRF juga berupaya melindungi hepar daripada mengalami kerosakan dengan merendahkan aras enzim hepar, alanine aminotransferae (ALT) dan aspartate aminotransferase (AST). Pengurangan kerosakan hepar tikus kumpulan TRF $+F N T$ juga telah diperhatikan secara histologi. Kesimpulannya, suplementasi TRF berpotensi memberikan kesan perlindungan pada hepar tikus aruhan FNT dengan mengurangkan kerosakan oksidatif dan meningkatkan status antioksidan.

Keywords: Antioksida; minyak sawit; tekanan oksidatif; vitamin E

\section{INTRODUCTION}

Uncontrolled application of organophosphate (OP) pesticides in agriculture and public health had increased the risk of toxicity to non-target organisms (Das \& Mukherjee 2000). Human exposure to low-dose pesticide may arise from nutritional (food and drinking water) or environmental sources and may leads to a long-lasting and negative health impact in the long-term (Hernandez et al. 2013). Fenitrothion (O,O-dimethyl O-(4-nitro-m-tolyl)- phosphorotioate) (FNT) is one of the most commonly used OP pesticides worldwide. It has been classified as class II (moderately toxic) compound by the WHO (2010) and has been categorised as one of the 'red list' substances by the European Union (EU) due to its toxicity effects towards the aquatic environment (Kozawa et al. 2009).

OP pesticides including FNT have also been reported to exert their primary toxic effects through the inhibition of cholinesterase enzyme (ChE). The irreversible inhibition 
of ChE leads to accumulation of the neurotransmitter acetylcholine and continuous stimulation of cholinergic receptors which then produced the sign and symptoms of toxicity (Hazarika et al.2003). However, previous research had reported that the inhibition of ChE enzyme did not fully explain the OP toxicity (Lukaszewicz-Hussain 2010).

As a principal organ for the drug metabolism and detoxification, liver is always prone to xenobiotic-induced injury mainly due to metabolite formation (Jaeschke et al. 2002). Liver function could be detrimentally altered, as it is the first organ to encounter the ingested nutrients, drugs and chemicals including OP pesticides (Al-Attar 2010). FNT at the dose of $20 \mathrm{mg} / \mathrm{kg}$ bw was found to cause injury to liver and kidney (Elhalwagy et al. 2008), pancreas (Budin et al. 2012) and damaged to sperm and testes (Taib et al. 2013) of experimental rats.

Repeated exposure of OP might induce oxidative stress in different tissues through the formation of reactive oxygen species (ROS) as reviewed by Abdollahi et al. (2004). The damage to membrane lipids, protein and DNA was reported to be the endpoint biomarker of oxidative stress-induced toxic effects of pesticide (Tuzmen et al. 2008). In order to reduce the toxic effects of op by targeting the oxidative stress mechanism, many studies had been done to evaluate the protective effects of various exogenous antioxidants such as vitamin E (Bhatti et al. 2010; Elhalwagy et al.2008).

Palm oil is one of the major sources of vitamin $E$ that consist both tocopherol and tocotrienol isoforms with the ratio of 24: 76 (Aggarwal et al.2010). Tocotrienol is one of the vitamin $E$ isomers which also possess numerous healthrelated properties that are not shared by other $\alpha$-tocopherols (Tiwari et al. 2009). Studies have shown that, tocotrienol rich fraction (TRF) of palm oil at the dose of $200 \mathrm{mg} / \mathrm{kg}$ bw $^{-1}$ possesses high antioxidant (Packer et al. 2001), antidiabetic (Budin et al. 2009) and anti-hypercholesterolemia (Qureshi et al. 1991) properties. Previous study has reported that TRF has attenuate liver injury induced by FNT in experimental rats (Jayusman et al. 2014). However, the status of oxidative damage was not showed. Thus, the present study was done to determine the ability of TRF in preventing FNT-induced liver oxidative damage in rats by evaluating lipid and protein oxidation and endogenous antioxidants status.

\section{MATERIALS AND METHODS}

\section{CHEMICALS}

Fenitrothion (Sumithion ${ }^{\circledR}, 99 \%$ purity) was purchased from Supelco Analytical, USA. Palm Oil Tocotrienol-rich Fraction (Gold Tri. E ${ }^{\circledR} 70$ ) was purchased from Sime Darby, Malaysia. All other chemicals were purchased from Merck, Germany.

\section{ANIMALS}

This study was conducted using male Sprague-Dawley rats $(n=40)$, weighing between 220 and $250 \mathrm{~g}$. The rats were obtained from the Animal Laboratory Unit of Universiti Kebangsaan Malaysia (UKM), Bangi, Malaysia. All rats were acclimatized for 1 week under the same laboratory conditions of temperature $\left(25^{\circ} \mathrm{C}\right.$ to $\left.28^{\circ} \mathrm{C}\right)$ with $12 \mathrm{~h} / 12$ $\mathrm{h}$ light/dark cycle and were supplied with standard diet and tap water ad libitum. All the experimental procedures involving the animals were carried out according to the animal ethics guidelines approved by the UKM Animal Ethic Committee (UKMAEC) with resolution number: FSKB/BIOMED/2010/BALKIS/14-JULY/311-AUGUST-2010JULY-2011.

\section{EXPERIMENTAL DESIGN}

Rats were randomly divided into four groups, namely Control, TRF, FNT and TRF+FNT groups. The Control group only received corn oil and TRF group received TRF (200 mg/ $\mathrm{kg} \mathrm{bw).} \mathrm{TRF} \mathrm{and} \mathrm{FNT} \mathrm{were} \mathrm{dissolved} \mathrm{in} \mathrm{corn} \mathrm{oil,} \mathrm{which} \mathrm{acts}$ as a vehicle. Rats in TRF+FNT group were supplemented with TRF (200 mg/kg bw) $30 \mathrm{~min}$ prior to $20 \mathrm{mg} / \mathrm{kg}$ bw of FNT both orally (Dirican \& Kalender 2012). The FNT dose chosen in this study was based on a previous research done by Elhalwagy et al. (2008) while TRF dose selection was based on a study done by Budin et al. (2009).

\section{PREPARATION OF SERUM AND TISSUE EXTRACT}

After the treatment period, rats were anaesthetised and blood samples were collected by cardiac puncture to obtain the plasma. The obtained plasma was stored at $-40^{\circ} \mathrm{C}$ for further analysis of oxidative stress and biochemical assay. The rats were sacrificed and liver obtained. Small slices of the liver were fixed in $10 \%$ formalin for histopathological evaluation. The remaining liver was homogenized with an Ultra Turrax T25 homogenizer in $50 \mathrm{mM}$ iced-cold phosphate buffer solution ( $\mathrm{pH} 7.4)$ containing $1.15 \% \mathrm{KCl}$ and $0.1 \mathrm{M}$ EDTA and centrifuged at $9000 \mathrm{~g}$ for $15 \mathrm{~min}$ at $4^{\circ} \mathrm{C}$ to produce $10 \%$ homogenate. Supernatants were collected, aliquot and stored at $-80^{\circ} \mathrm{C}$ for further analysis of oxidative stress and antioxidant status assay.

\section{CHOLINESTERASE AND LIVER ENZYMES ASSAY}

Cholinesterase enzyme (ChE), alanine aminotransferase (ALT) and aspartate aminotransferase (AST) activities were determined by a semi-automated bioanalyzer BTS-350 (Biosystems S.A., Barcelona, Spain).

\section{OXIDATIVE STRESS AND ANTIOXIDANT STATUS}

The homogenised liver and plasma samples were assessed for oxidative stress markers which were malondialdehyde (MDA) and protein carbonyl using the methods of Stock and Dormandy (1971) and Levine et al. (1990), respectively. The levels of reduced glutathione (GSH) and ferric-reducing antioxidant power (FRAP) were assessed according to the method of Benzie and Strain (1999) and Ellman (1959), respectively. Antioxidant enzymes such as glutathione S-transferase (GST), catalase (CAT), superoxide dismutase 
(SOD) and glutathione peroxidase (GPX) were measured in liver homogenate based on method done by Aebi (1984), Beyer and Fridovich (1987), Habig and Jacoby (1974) and Lawrence and Burk (1976), respectively.

\section{HISTOPATHOLOGICAL EXAMINATION}

The fixed liver was processed in graded series of alcohols and embedded in paraffin wax. The paraffin blocks were sectioned at $4 \mu \mathrm{m}$ thick and these sections were stained with haematoxylin and eosin (H\&E) for histological observation under the light microscope.

\section{STATISTICAL ANALYSIS}

The results were expressed as means \pm standard deviation. All data were analysed using the Statistical Package for Social Sciences (SPSS 17.0). The results were analyzed using one way analysis of variance (ANOVA) followed by Tukey's test for multiple comparisons. Statistical significant was set at $p<0.05$.

\section{RESULTS}

\section{EFFECTS OF TRF ON BODY WEIGHT AND LIVER WEIGHT}

The final body weight and liver (absolute and relative) weights of FNT group were significantly reduced compared to control and TRF groups $(p<0.05)$. TRF administration was able to significantly increase the body weight and absolute liver weight in TRF+FNT group compared to FNT group $(p<0.05)$. However, the relative liver weight was not significantly different (Table 1).

\section{EFFECTS OF TRF ON CHE AND LIVER ENZYMES ACTIVITIES}

Table 2 shows a significant reduction in ChE activity and elevation of ALT and AST in the plasma of FNT group compared to control and $\operatorname{TRF}_{\text {groups }}(p<0.05)$. TRF supplementation significantly reduced the ALT and AST enzymes activities in TRF+FNT group compared to FNT group $(p<0.05)$. However, no significant difference was found for ChE in TRF+FNT group compared to FNT group alone.

\section{EFFECTS OF TRF ON OXIDATIVE STRESS MARKERS AND ANTIOXIDANT STATUS}

Table 3 shows the level of MDA, PC, GSH and FRAP value in the plasma of the experimental groups. In comparison with the control and TRF groups, the levels of plasma MDA and PC were significantly elevated in FNT rats $(p<0.05)$. Meanwhile, the level of GSH and FRAP value were significantly decreased in FNT group compared to the control group $(p<0.05)$. TRF supplementation significantly decreased PC levels and significantly increased FRAP

TABLE 1. Final body weight, absolute and relative liver weight of experimental rats

\begin{tabular}{lcccc}
\hline Parameters and treatments & Control & TRF & FNT & TRF+FNT \\
\hline Final body weight $(\mathrm{g})$ & $354.3 \pm 9.97$ & $343.5 \pm 21.42$ & $269.28 \pm 10.63^{\mathrm{a}, \mathrm{b}}$ & $300.00 \pm 21.89^{\mathrm{a}, \mathrm{b}, \mathrm{c}}$ \\
Absolute liver weight $(\mathrm{g})$ & $9.78 \pm 1.02$ & $9.51 \pm 1.86$ & $6.49 \pm 0.67^{\mathrm{a}, \mathrm{b}}$ & $7.6 \pm 0.82^{\mathrm{a}, \mathrm{b}, \mathrm{c}}$ \\
Relative liver weight $(\%)$ & $2.82 \pm 0.17$ & $2.83 \pm 0.43$ & $2.35 \pm 0.18^{\mathrm{a}, \mathrm{b}}$ & $2.53 \pm 0.20$ \\
\hline
\end{tabular}

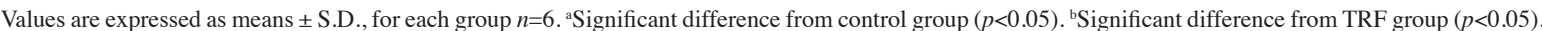

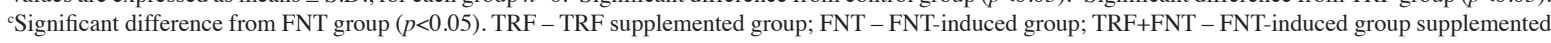
with TRF

TABLE 2. Effect of TRF supplementation on plasma ChE and liver enzymes in experimental rats

\begin{tabular}{lcccc}
\hline Parameters & Control & TRF & FNT & TRF+FNT \\
\hline ChE (U/L) & $469.00 \pm 19.4$ & $415.25 \pm 53.41$ & $320.14 \pm 45.61^{\mathrm{a}, \mathrm{b}}$ & $378.42 \pm 50.28$ \\
ALT (U/L) & $50.43 \pm 6.80$ & $53.17 \pm 8.68$ & $68.79 \pm 4.12^{\mathrm{a}, \mathrm{b}}$ & $53.43 \pm 7.20^{\mathrm{c}}$ \\
AST (U/L) & $126.64 \pm 19.45$ & $125.71 \pm 22.50$ & $167.64 \pm 19.74^{\mathrm{a}, \mathrm{b}}$ & $131.64 \pm 21.53^{\mathrm{c}}$ \\
\hline
\end{tabular}

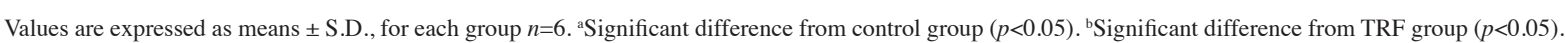
'Significant difference from FNT group $(p<0.05)$. TRF - TRF supplemented group; FNT - FNT-induced group; TRF+FNT - FNT-induced group supplemented with TRF

TABLE 3. Effect of TRF supplementation on plasma oxidative stress marker and antioxidant status in experimental rats

\begin{tabular}{lcccc}
\hline Parameters & Control & TRF & FNT & TRF+FNT \\
\hline MDA equivalent $(\mu$ mol/mg protein $)$ & $0.066 \pm 0.012$ & $0.069 \pm 0.020$ & $0.108 \pm 0.027^{\mathrm{a}, \mathrm{b}}$ & $0.090 \pm 0.008$ \\
PCO $(\mathrm{nmol} / \mathrm{mg}$ protein) & $0.034 \pm 0.004$ & $0.034 \pm 0.003$ & $0.050 \pm 0.009^{\mathrm{a}, \mathrm{b}}$ & $0.037 \pm 0.008^{\mathrm{c}}$ \\
GSH $(\mu \mathrm{mol} / \mathrm{mg}$ protein) & $6.63 \pm 1.09$ & $6.19 \pm 0.22$ & $4.85 \pm 0.58^{\mathrm{a}, \mathrm{b}}$ & $5.59 \pm 0.43$ \\
FRAP value $(\mu \mathrm{M})$ & $0.332 \pm 0.068$ & $0.291 \pm 0.076$ & $0.171 \pm 0.030^{\mathrm{a}, \mathrm{b}}$ & $0.273 \pm 0.056^{\mathrm{c}}$ \\
\hline
\end{tabular}

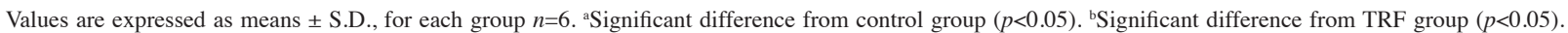
'Significant difference from FNT group $(p<0.05)$. TRF- TRF supplemented group; FNT - FNT-induced group; TRF+FNT - FNT-induced group supplemented with TRF 
value in plasma of TRF+FNT group compared to FNT group $(p<0.05)$.

In Table 4, FNT caused a significant elevation of hepatic MDA and PC levels compared to control and TRF groups $(p<0.05)$. Conversely, FNT rats supplemented with TRF showed a marked reduction in MDA and PC levels compared to FNT group alone $(p<0.05)$. FNT-intoxication resulted in a lower GSH level, FRAP value, SOD, GPX, CAT and GST activities $(p<0.05)$ when compared to control and TRF groups. Supplementation of TRF to FNT group significantly increased the hepatic GSH level, FRAPvalue and GPX activity compared to FNT group $(p<0.05)$.

\section{EFFECTS OF TRF ON LIVER HISTOPATHOLOGICAL OBSERVATION}

By the light microscopic observation, the control and TRF rats showed a normal histoarchitecture of liver as presented in Figure 1(a) and 1(b). Cords of hepatocytes were radiated from a central vein towards periphery and separated from each other by the sinusoid. Centrally located nucleolus and distinct nucleoli were observed at higher magnification. Figure 1(c) and 1(d) shows marked alterations of liver histopathology in FNT-treated rats. Haemorrhage, degeneration of hepatic cords and ballooning of hepatocytes with areas of necrosis were observed. In contrast, TRF supplementation ameliorated the histopathological changes in the liver tissue of TRF+FNT rat (Figure 1(e) and 1(f)). Haemorrhage and necrosis were absent and the structure of the hepatic lobule was preserved. However, mild pyknotic cells were still present.

\section{DISCUSSION}

Human epidemiological and animal experimental data indicated that the OP compounds including FNT can be quickly absorbed from the skin and gastrointestinal tract due to its lipid-soluble nature. Because of its widespread use on fruits, vegetables and stored grains, FNT is the most common insecticide residue found in food (Meaklim et al. 2003) which could lead to cross-contamination to nontarget organism. Although FNT was given at $1 / 30$ of the oral
$\mathrm{LD}_{50}$, we observed pathological changes in the rat's liver. The present study has showed the beneficial effect of TRF in preventing oxidative liver damage in rats expose to FNT.

Inhibition of ChE activity is an important indicator of OP poisoning. In this study, cholinergic crisis was observed whereby $\mathrm{ChE}$ activity was found to be inhibited following FNT exposure while, the supplementation of TRF increase this enzyme activity marginally. Hence, TRF showed a potential in protecting the inhibition of ChE activities but it was not a total protection as described in a previous study (Bhatti et al. 2010). Vitamin $\mathrm{E}$ is able to protects $\mathrm{ChE}$ by preventing the phosphorylation activity (Verma et al. 2007). Due to the inhibition of ChE, a marked decreased in final body weight was found in FNT group which was similar to the study using the dimethoate-intoxicated rats (Saafi et al. 2011). Supplementation of TRF increased the final body weight and absolute liver weight of FNT rats which might be due to its ability to increase rat's appetite and the reduction of cholinergic crisis in op toxicity (ElMazoudy et al. 2011).

Besides the inhibition of AChE activity, oxidative stress has also been classified as one of the toxicity mechanisms involved in OP repeated exposure (Lukaszewicz-Hussain 2010). The present results showed that FNT induced oxidative damage of liver by increasing lipid and protein oxidation and altering the enzymatic and non-enzymatic antioxidants status. Supplementation of TRF showed the ability in counteracting the oxidative liver damage possibly through the increasing in free radical scavenging activity and improving the antioxidant status which in line with the previous research (Bhatti et al. 2010; Elhalwagy et al. 2008). In addition, the reducing of oxidative damage also seen in parameters measured in plasma, which also support the role of TRF as exogenous antioxidant in biological system (Budin et al. 2009).

TRF possessed its antioxidant activity through the ability of tocotrienol and tocopherol to donate phenolic hydrogens (electrons) to lipid radicals (Kamal-Eldin \& Appelqvist 1996), suggesting that the antioxidant properties of both vitamin $\mathrm{E}$ isoforms in TRF might be responsible for the liver protection against the oxidative stress. The presence of double bonds in the structure of tocotrienol made it highly unsaturated and very efficient

TABLE 4. Effect of TRF supplementation on liver oxidative stress marker and antioxidant status in experimental rats

\begin{tabular}{lcccc}
\hline Parameters & Control & TRF & FNT & TRF+FNT \\
\hline MDA equivalent $(\mu \mathrm{mol} / \mathrm{mg}$ protein) & $0.340 \pm 0.027$ & $0.357 \pm 0.045$ & $0.481 \pm 0.060^{\mathrm{a}, \mathrm{b}}$ & $0.350 \pm 0.023^{\mathrm{c}}$ \\
PCO (nmol/mg protein) & $0.074 \pm 0.144$ & $0.078 \pm 0.013$ & $0.119 \pm 0.010^{\mathrm{a}, \mathrm{b}}$ & $0.095 \pm 0.020^{\mathrm{c}}$ \\
GSH ( $\mu \mathrm{mol} / \mathrm{mg}$ protein) & $6.18 \pm 0.78$ & $6.03 \pm 0.85$ & $4.81 \pm 0.45^{\mathrm{a}, \mathrm{b}}$ & $5.98 \pm 0.44^{\mathrm{c}}$ \\
FRAP value $(\mu \mathrm{M})$ & $0.895 \pm 0.05$ & $0.852 \pm 0.04$ & $0.726 \pm 0.06^{\mathrm{a}, \mathrm{b}}$ & $0.862 \pm 0.04^{\mathrm{c}}$ \\
SOD (unit/mg protein) & $0.593 \pm 0.044$ & $0.548 \pm 0.019$ & $0.513 \pm 0.047^{\mathrm{a}, \mathrm{b}}$ & $0.528 \pm 0.039$ \\
CAT (unit/mg protein) & $0.216 \pm 0.008$ & $0.196 \pm 0.009$ & $0.183 \pm 0.012^{\mathrm{a}, \mathrm{b}}$ & $0.195 \pm 0.018$ \\
GPx (nmol/min/mg protein) & $3.98 \pm 0.14$ & $3.80 \pm 0.33$ & $3.28 \pm 0.13^{\mathrm{a}, \mathrm{b}}$ & $3.73 \pm 0.27^{\mathrm{c}}$ \\
GST (nmol/min/mg protein) & $4.29 \pm 0.24$ & $4.23 \pm 0.34$ & $3.73 \pm 0.31^{\mathrm{a}, \mathrm{b}}$ & $4.09 \pm 0.29$ \\
\hline
\end{tabular}

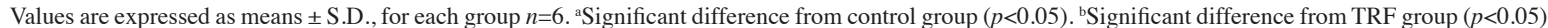
${ }^{c}$ Significant difference from FNT group $(p<0.05)$. TRF - TRF supplemented group; FNT - FNT-induced group; TRF+FNT - FNT-induced group supplemented with TRF 

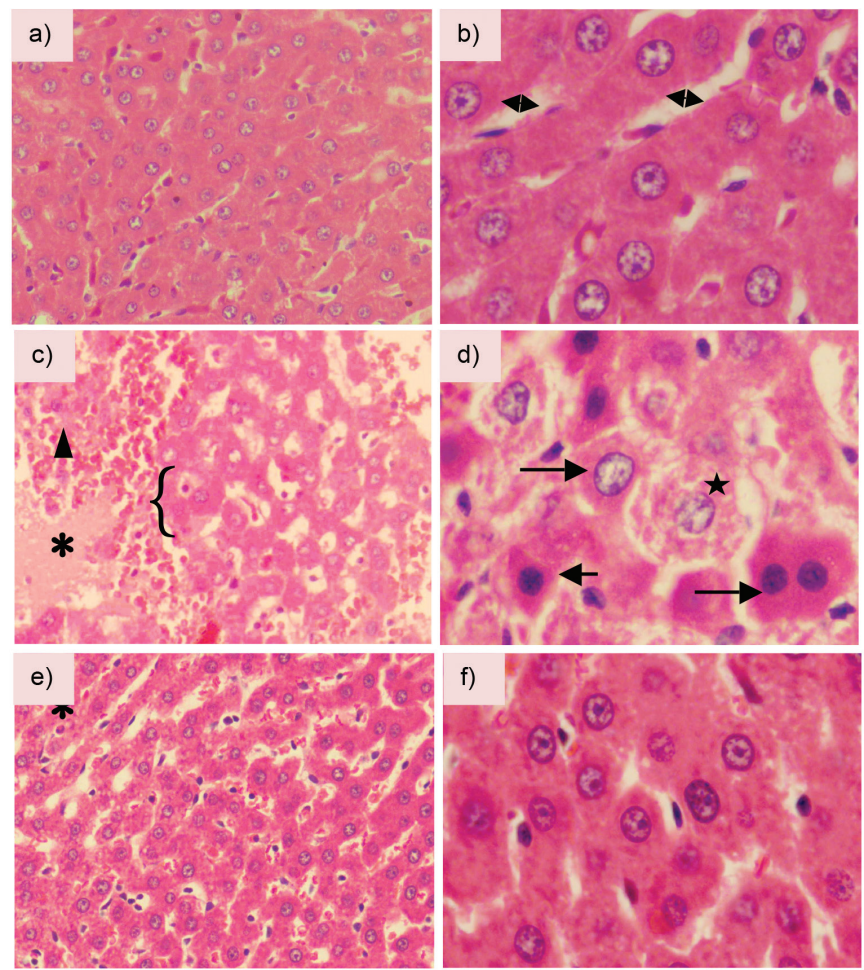

FIGURE 1. Representative histopathology slides of Haematoxylin and Eosin (H\&E) staining in the liver tissue of experimental rats. Figure 1(a) and 1(b) shows normal liver structure of control group and TRF group. (a) Cords of hepatocytes radiated from central vein are separated by sinusoids containing Kuppfer cells $(\leftrightarrow)(\times 40)$, (b) In higher magnification, roughly uniform nucleus and nucleolus were seen $(\times 100),(c)$ Liver sections of FNT-intoxicated rats showed disruption of hepatic cords $(\{)$, (d) Necrotic area $(*)$ and severe haemorrhage (triangle). Ballooning of hepatocytes (star) and pyknotic cells (arrow) were clearly seen in higher magnification $(\times 100)$. Liver sections of TRF+FNT rats showed histopathological changes of hepatocytes with attenuated severity $((\mathrm{e}) \times 40$ and $(\mathrm{f}) \times 100)$.

Some improvements like the absence of severe haemorrhage and necrosis were observed

in penetrating the saturated fatty layers of liver and brain tissues (Suzuki et al. 1993). The interaction between the radical molecule and vitamin $\mathrm{E}$ would therefore stop the propagation of the peroxyl radical chain reaction (Packer et al.2001) and alleviate the oxidative stress response.

The increase in ROS formation would explain a number of deleterious effects such as membrane damage and loss of cellular integrity (Anderson \& Borlak 2007) in the liver. The injury to hepatocytes following OP pesticide intoxication would cause the release of cytosolic enzymes into blood circulation (Elhalwagy et al. 2008). In the present study, plasma ALT and AST levels were increased in FNT-intoxicated rats. Reduction in the levels of plasma ALT and AST towards the normal values in TRF supplemented rats indicated that TRF protect the structural integrity of the hepatocyte membrane thus preventing the leakage of its cytosolic enzymes (Bhatti et al. 2010).

The microscopic observations showed that TRF prevent various histopathological alterations in liver cause by FNT which includes vascular congestion, disruption of hepatocytes and cellular necrosis. The morphological alterations were consistent with the liver enzymes levels that have been initially observed. The present findings suggested that TRF could attenuate the oxidative damage of liver due to the harmful effects of FNT. This finding is consistent with study done by Bhatti et al. (2010) that shows the supplementation of vitamin E modulate the hepatotoxicity and oxidative stress in experimental rats.

\section{CONCLUSION}

In conclusion, the findings of the current study demonstrated that exogenously TRF was capable in protecting the oxidative toxic effects of subchronic FNT exposure. The hepatoprotective effect of TRF can be correlated to its antioxidant activity. In spite of the ameliorative effect of TRF supplementation on some biochemical parameters, it may need more time to confer full protection towards the liver and other organs. Further studies are still needed to evaluate the other underlying mechanisms of TRF protection in FNT-induced liver damage. Moreover, studies can be done to evaluate the reversible effects or the recovery level of the organ and their functions by stopping the intoxication with FNT and prolonging the duration of TRF supplementation.

\section{ACKNOWLEDGEMENTS}

The authors would like to express their gratitude to the Ministry of Higher Education (MOHE), Malaysia and 
Universiti Kebangsaan Malaysia for providing the financial assistance under the 'UKM-NN-03-FRGS0042-2010' research grant.

\section{REFERENCES}

Abdollahi, M., Ranjbar, A., Shadnia, S., Nikfar, S. \& Rezaie, A. 2004. Pesticides and oxidative stress: A review. Med. Sci. Monit. 10(6): RA141-147.

Aebi, H. 1984. Catalase in vitro. Methods Enzymol. 105: 121-126.

Aggarwal, B.B., Sundaram, C., Prasad, S. \& Kannappan, R. 2010. Tocotrienols, the vitamin $\mathrm{E}$ of the 21 st century: Its potential against cancer and other chronic diseases. Biochem. Pharmacol. 80(11): 1613 - 1631.

Al-Attar, A.M. 2010. Physiological and histopathological investigations on the effects of $\alpha$ - lipoic acid in rats exposed to malathion. J.Biomed.Biotechnol. 2010: Article ID 203503. DOI. $10.1155 / 2010 / 203503$.

Anderson, N. \& Borlak, J. 2007. Mechanisms of toxic liver injury. In Hepatotoxicity. From Genomics to in vitro and in vivo Models, edited by Sahu, S.C. New York: John Wiley \& Sons Ltd. pp. 191-286.

Benzie, I.F.F. \& Strain, J.J. 1999. Ferric reducing/antioxidant power assay: Direct measure of total antioxidant activity of biological fluids and modified version for simultaneous measurement of total antioxidant power and ascorbic acid concentration. Methods in Enzymology 299: 15-27.

Beyer, J. \& Fridovich, I. 1987. Assaying for superoxide dismutase activity: Some large consequences of minor changes in conditions. Anal. Biochem. 161(2): 559-566.

Bhatti, G.K., Kiran, R. \& Sandhir, R. 2010. Modulation of ethioninduced hepatotoxicity and oxidative stress by vitamin $\mathrm{E}$ supplementation in male wistar rats. Pestic. Biochem. Phys. 98: 26-32.

Budin, S.B., Othman, F., Louis, S.R., Bakar, M.A., Das, S. \& Mohamed, J. 2009. The effects of palm oil tocotrienol rich fraction supplementation on biochemical parameters, oxidative stress and the vascular wall of streptozotocininduced diabetic rats. Clinics 64(3): 235-244.

Budin, S.B., Han, C.M., Jayusman, P.A. \& Taib, I.S. 2012. Tocotrienol rich fraction prevents fenitrothion induced pancreatic damage by restoring antioxidant status. Pak. J. Biol. Sci. 15(11): 517-523.

Das, B. \& Mukherjee, S. 2000. Chronic toxic effects of quinalphos on some biochemical parameters in Labeo Rohita (Ham.). Toxicol. Lett. 114(1): 11-18.

Dirican,E.K. \& Kalender, Y. 2012. Dichlorvos-induced testicular toxicity in male rats and the protective role of vitamins $\mathrm{C}$ and E. Experimental and Toxicologic Pathology 64(7): 821-830.

Elhalwagy, M.E.A., Darwish, N.S. \& Zaher, E.M. 2008. Prophylactic effect of green tea polyphenols against liver and kidney injury induced by fenitrothion insecticide. Pestic. Biochem. Phys. 91: 81-89.

Ellman, G.L. 1959. Tissue sulfhydryl groups. Arch. Biochem. Biophys. 82(1): 70-77.

ElMazoudy, R.H., Attia, A.A. \& AbdElGawad, H.S. 2011. Evaluation of developmental toxicity induced by anticholinesterase insecticide, diazinon in female rats. Development and Reproductive Toxicology 92: 534-542.

Habig, W.H., Pabst, M.J. \& Jakoby, W.B. 1974. Glutathione S-transferases the first enzymatic step in mercapturic acid formation. J. Biol. Chem. 249(22): 7130-7139.
Hazarika, A., Sarkar, S.N., Hajare, S., Kataria, M. \& Malik, J.K. 2003. Influence of malathion pretreatment on the toxicity of anilofos in male rats: A biochemical interaction study. Toxicology 185: 1-8.

Hernández, A.F., Parrón, T., Tsatsakis, A.M., Requena, M., Alarcón, R. \& López-Guarnido, O. 2013. Toxic effects of pesticide mixtures at a molecular level: Their relevance to human health. Toxicology 307: 136-145.

Jaeschke, H., Gores, G.J., Cederbaum, A.I., Hinson, J.A., Pessayre, D. \& Lemasters, J.J. 2002. Mechanisms of hepatotoxicity. Toxicol. Sci. 65(2): 166-176.

Jayusman, P.A., Budin, S.B., Ghazali, A.R., Taib, I.S. \& Louis, S.R. 2014. Effects of palm oil tocotrienol-rich fraction on biochemical and morphological alterations of liver in fenitrothion-treated rats. Pakistan Journal of Pharmaceutical Sciences 27(6): 1873-1880.

Kamal-Eldin, A. \& Appelqvist, L-Å. 1996. The chemistry and antioxidant properties of tocopherols and tocotrienols. Lipids 31(7): 671-701.

Kozawa, K., Aoyama, Y., Mashimo, S. \& Kimura, H. 2009. Toxicity and actual regulation of organophosphate pesticides. Toxin Reviews 28(4): 245-254.

Lawrence, R.A. \& Burk, R.F. 1976. Glutathione peroxidase activity in selenium-deficient rat liver. Biochem.Bioph. Res. Co. 71(4): 952-958.

Levine, R.L., Garland, D., Oliver, C.N., Amici, A., Climent, I., Lenz, A-G., Ahn, B-W., Shaltiel, S. \& Stadtman, E.R. 1990. Determination of carbonyl content in oxidatively modified proteins. Methods Enzymol. 186: 464-478.

Lukaszewicz-Hussain, A. 2010. Role of oxidative stress in organophosphate insecticide toxicity - Short review. Pest. Biochem. Physiol. 98: 145-150.

Meaklim, J., Yang, J., Drummer, O.H., Killalea, S., Staikos, V., Horomidis, S., Rutherford, D., Ioannides-Demos, L.L., Lim, S. \& Mclean, A.J. 2003. Fenitrothion: Toxicokinetics and toxicologic evaluation in human volunteers. Environmental Health Perspectives 111(3): 305-308.

Packer, L., Weber, S.U. \& Rimbach, G. 2001 . Molecular aspects of $\alpha$-tocotrienol antioxidant action and cell signalling. J.Nutr. 131(2): 369S-373S.

Qureshi, A.A., Qureshi, N., Wright, J.J., Shen, Z., Kramer, G., Gapor, A., Chong, Y.H., DeWitt, G., Ong, A. \& Peterson, D.M 1991. Lowering of serum cholesterol in hypercholesterolemic humans by tocotrienols (palmvitee). Am. J. Clin. Nutr. 53(4 Suppl): 1021S-1026S.

Saafi, E.B., Louedi, M., Abdelfattah, E., Zakhama, A., Najjar, M.F., Hammamia, M. \& Achour, L. 2011. Protective effect of date palm fruit extract (Phoenix dactylifera $\mathrm{L}$.) on dimethoate induced-oxidative stress in rat liver. Exp. Toxicol. Pathol. 63: 433-441.

Stocks, J. \& Dormandy, T. 1971. The autoxidation of human red cell lipids induced by hydrogen peroxide. Brit. J. Haematol. 20(1): 95-111.

Suzuki, Y.J., Tsuchiya, M., Wassall, S.R., Choo, Y.M., Govil, G., Kagan, V.E. \& Packer, L. 1993. Structural and dynamic membrane properties of $\alpha$-tocopherol and $\alpha$-tocotrienol: Implication to the molecular mechanism of their antioxidant potency. Biochem. 32(40): 10692-10699.

Taib, I.S., Budin, S.B., Ghazali, A.R., Jayusman, P.A., Louis, S.R. \& Mohamed, J. 2013. Fenitrothion induced oxidative stress and morphological alterations of sperm and testes in male sprague-dawley rats. Clinics 68(1): 93-100. 
Tiwari, V., Kuhad, A., Bishnoi, M. \& Chopra, K. 2009. Chronic treatment with tocotrienol, an isoform of vitamin E, prevents intracerebroventricular streptozotocin-induced cognitive impairment and oxidative-nitrosative stress in rats. Pharmacol. Biochem. Be.93(2): 183-189.

Tuzmen, N., Candan, N., Kaya, E. \& Demiryas, N. 2008. Biochemical effects of chlorpyrifos and deltamethrin on altered antioxidative defense mechanisms and lipid peroxidation in rat liver. Cell Biochemistry and Function 26(1): 119-124.

Verma, R.S., Mehta,A.\& Srivastava, N. 2007. In vivo chlorpyrifos induced oxidative stress: Attenuation by antioxidant vitamins. Pestic. Biochem. Phys. 88(2): 191-196.

WHO. 2010. The WHO Recommended Classification of Pesticides by Hazard and Guidelines to Classification 2009. Geneva: World Health Organization.
Programme of Biomedical Science

School of Diagnostic and Applied Health Sciences

Faculty of Health Sciences

Universiti Kebangsaan Malaysia

Jalan Raja Muda Abdul Aziz

50300 Kuala Lumpur, Federal Territory

Malaysia

*Corresponding author; email: balkis@ukm.edu.my

Received: 24 March 2016

Accepted: 6 July 2017 